\title{
Assessment of the Microbial Occupational Work Environment in One Faculty of King Abdulaziz University in Jeddah
}

\author{
Mansour Ahmed Balkhyour and Ahmed Mohamed Moawad Mabrouk
}

\author{
Environmental sciences Dept., Faculty of Meteorology, Environment and Arid Land Agriculture, \\ King Abdulaziz University, Jeddah, Saudi Arabia
}

\begin{abstract}
The presence of microorganisms in indoor air can pose serious health problems so; the purpose of the present work was to monitor the different groups of microorganisms including total viable bacteria, Staphylococci, total coliforms, Salmonella and fungi in different sites of the occupational environment (laboratories, offices, corridors and toilets) inside the Faculty of Metrology, Environment and Arid Land Agriculture, King Abdulaziz University, Jeddah, Saudi Arabia. The results showed that, the average of total viable bacterial counts in different work laboratories was ranged from 9500 to 23000, Staphylococci counts were ranged from 584 to 11000 and fungi counts were ranged from 383 to $2500 \mathrm{cfu} / \mathrm{m}^{3}$. On the other hand the total viable bacterial counts in work offices varied from 12700 to $26500 \mathrm{cfu} / \mathrm{m}^{3}$, meanwhile Staphylococci counts ranged from 5000 to $9500 \mathrm{cfu} / \mathrm{m}^{3}$ and fungi counts ranged from 1500 to $4833 \mathrm{cfu} / \mathrm{m}^{3}$. Also, the total viable bacterial counts in corridors ranged from 14340 to $23700 \mathrm{cfu} / \mathrm{m}^{3}$, Staphylococci counts ranged from 3167 to $10340 \mathrm{cfu} / \mathrm{m}^{3}$ and fungi counts ranged from 2830 to $5165 \mathrm{cfu} / \mathrm{m}^{3}$. Finally, the average of the total viable bacterial counts in toilets reached $22833 \mathrm{cfu} / \mathrm{m}^{3}$. Meanwhile, Staphylococci counts were $4920 \mathrm{cfu} / \mathrm{m}^{3}$ and fungi counts were $3010 \mathrm{cfu} / \mathrm{m}^{3}$. The highest average of total viable bacterial counts were found in toilets $\left(22833 \mathrm{cfu} / \mathrm{m}^{3}\right)$, the highest average of Staphylococci counts recorded $\left(7811 \mathrm{cfu} / \mathrm{m}^{3}\right)$ in corridors and the highest average of fungi counts were observed in laboratories $\left(4516 \mathrm{cfu} / \mathrm{m}^{3}\right)$. It is clear that the toilets had the highest average of total viable bacterial counts, the corridors had the highest average of Staphylococci counts and laboratories had the highest average of fungi. The microbial groups of coliforms, yeasts and Salmonella were not detected in all sampling sites (laboratories, offices, corridors and toilets). Finally, an attention must be given in the place to protect and enhance the occupational environment and keep health of students and workers well.
\end{abstract}

Keywords: Indoor air, microorganisms, airborne bacteria, health problems and occupational environment.

\section{Introduction}

In recent years, there has been a growing interest in indoor microbiological studies because long time of our life was spent indoors like houses, work offices, campus and schools.
Also, people inhale 10 to $14 \mathrm{~m}^{3}$ of the air every day and spend between $80-95 \%$ of their lives indoors (Abdel Hameed and Farag 1999 and Dacarro et al. 2003). Indoor air pollution in classrooms may increase the chance of short- and long-term health problems for 
students and staff reducing teachers' productivity student's learning possibilities (Shaughnessy et al. 2012). Bioaerosols decrease air quality and affect human health, also causing some diseases such as tuberculosis, diphtheria, legionellosis, fever, rhinitis, nausea and asthma. Indoor air quality is becoming an increasingly important issue for occupational and public health because of $30 \%$ of health problems is relevant to the indoor air pollutants (Reynolds, et al. 2001; Srikanth et al. 2008 and Dudzińska, 2011).

The air quality of indoor work environment is one of the main factors affecting health and one of main problems is the presence of microorganisms including bacteria, moulds and viruses (WHO, 2013 and Wamedo et al. 2012). The investigation of air quality contributes not only assessing indoor pollution levels, but also implementing corrective measures to improve air quality.

An indoor air pollution results from the combination of physical, chemical, biological factors and ventilation in the environment. Also, the other indoor sources of air pollution are heating, and air conditioning systems, building equipment, furnishings, and human activities (Jurado, et al., 2014).

The bio contaminants sources of indoor air may enter indoor areas either by means of passive ventilation or by means of ventilation systems. Many genera are also emitted by indoor sources like animals, flowerpots and wastebaskets.

In most cases, normal flora is not harmful. However, growth conditions like excessive humidity and/or a high water content of building materials are encountered on more frequent basis, which in most cases can be described as the limiting factor for microbial growth (Dhanasekaran et al., 2009). Moreover, Kalwasinska, et al. (2012) mentioned that, possible sources of biological contamination of indoor air of working environment include peoples, organic fine dust, various materials found in the buildings, and the air inflowing from the ventilation and air conditioning closed systems.

The air inhaled by people is abundantly populated with microorganisms which form so-called bioaerosol. Bioaerosol is a colloidal suspension formed by liquid droplets and particles of solid matter in the air, whose components contain or have attached to them viruses, fungal spores and conidia, bacterial endospores, plant pollen and fragments of plant tissues (Karwowska, 2005 and Kalwasinska et al. 2012).

The sampling and analysis of microbial load in indoor air has attracted more attention. Indoor air contamination may present a great risk to human health. The most indoor air pollutants are airborne microorganisms including bacteria and fungi which are normal and essential components of all environments.

These microorganisms are reported to be responsible for many health problems, especially among children who are sensitive to indoor pollutants more than adults, because they are still developing physically (Karwowska, 2005; Kim and Kim 2007; Huttunen, et al. 2008 and Stanley, et al. 2008).

The aim of the present study is to estimate the indoor microbial air quality in four different sites (laboratories: 13 locations, offices: 10 locations, corridors: 7 locations and toilets: 2 locations) in Faculty of Metrology, Environment and Arid Land Agriculture, King Abdu-Aziz University, Jeddah, Saudi Arabia.

\section{Materials and Methods}

In this study the research work was carried out in some different sites including offices, laboratories, corridors and toilets for counting of total viable bacteria, Staphylococci, total coliform bacteria, Salmonella and fungi. 
Triplicate samples were taken from all different sites in the morning at 8 to $10 \mathrm{am}$.

\section{Cultural media}

Standard plate count agar (Oxoid) a medium was used for counting the total viable bacteria, Rose Bengal Chloramphenicol agar (HiMedia) was used for enumerating fungi, Baird parker egg yolk tellurite emulsion agar was used for counting of Staphylococci, Violet red bile agar (HiMedia) was used for counting total coliforms and Brilliant green agar base with sulpha supplement (HiMedia) was used for enumerating Salmonella.

After air sampling, the plates were incubated at $37^{\circ} \mathrm{C} / 24-48 \mathrm{~h}$ for bacteria and at $27^{\circ} \mathrm{C} / 3-5$ days for fungi (Karwowska, 2005; Stryjakowska Sekulska, et al. 2007 and Hayleeyesus and Manaye 2014).

\section{Air sampling}

The high-efficiency microbial air sampler (Sampl'air ${ }^{\circledR}$ Lite AES CHEMUNEX, France) was used for enumerating the counts of microorganisms directly in elevated convex petri plates loaded with different media depending on the tested microorganisms in sampling points for 10 minutes.

The numbers of microorganisms were expressed as colony forming unit/cubic meter of air using the following equation (Stryjakowska Sekulska, et al. 2007).

$$
\mathrm{CFU} / \mathrm{m}^{3}=\mathrm{a} \cdot 10000 / \mathrm{p} \cdot \mathrm{t} \cdot 0.2
$$

Where: a - The number of colonies on the Petri plate

$\mathrm{p}$ - The surface area of the petri plate

$\mathrm{t}$ - The time of petri plate exposure

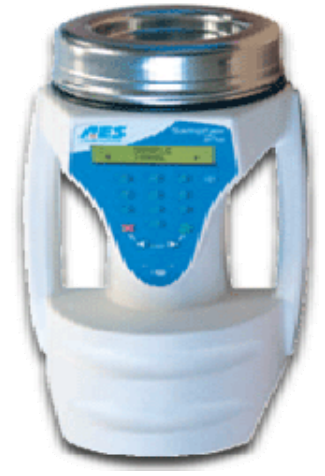

Fig. 1. The microbial air sampler (Sampl'air ${ }^{\circledR}$ Lite AES CHEMUNEX, France).

\section{Results and Discussion}

The microbial groups of coliforms, yeasts and Salmonella were not detected in all sampling sites (laboratories, offices, corridors and toilets). The microbial counting results were varied depending on sampling locations. The data in Figure (2) shows the colony forming unit (cfu) of the detected groups in laboratories. The counts of total viable bacteria, Staphylococci and fungi $\left(\mathrm{cfu} / \mathrm{m}^{3}\right)$ were ranged from 9500 to $23000 \mathrm{cfu} / \mathrm{m}^{3}, 584$ to $11000 \mathrm{cfu} / \mathrm{m}^{3}$ and 383 to $2500 \mathrm{cfu} / \mathrm{m}^{3}$, respectively.

Figure (3) illustrates the counts $\mathrm{cfu} / \mathrm{m}^{3}$ ) of the same microbial groups in offices. The counts of these groups varied from 12700 to $26500 \mathrm{cfu} / \mathrm{m}^{3}$ for total viable bacteria, 5000 to $9500 \mathrm{cfu} / \mathrm{m}^{3}$ for Staphylococci and from 1500 to $4833 \mathrm{cfu} / \mathrm{m}^{3}$ for fungi.

The results in Figure (4) shows, the total viable bacterial, Staphylococcal and fungal counts $\left(\mathrm{cfu} / \mathrm{m}^{3}\right)$ in corridors. The recorded counts ranged from 14340 to $23700 \mathrm{cfu} / \mathrm{m}^{3}$ for total viable bacteria, 3167 to $10340 \mathrm{cfu} / \mathrm{m}^{3}$ for Staphylococci and 2830 to $5165 \mathrm{cfu} / \mathrm{m}^{3}$ for fungi. The total viable bacteria were recorded 22500 and $23166 \mathrm{cfu} / \mathrm{m}^{3}$ in toilet one and two, respectively.

Also, the counts were 5500 and 4340 for Staphylococci and 2833 and 3187 for fungi in 
the same 2 locations, respectively (fig 5). The obtained results showed that the highest general means of total viable bacterial counts $\left(22833 \mathrm{cfu} / \mathrm{m}^{3}\right)$ was observed in the samples taken from toilets followed by the samples taken from corridors $\left(19435 \mathrm{cfu} / \mathrm{m}^{3}\right)$.

Also, the means of total viable bacterial counts detected in the samples taken from laboratories were $17548 \mathrm{cfu} / \mathrm{m}^{3}$ and the lowest total viable bacterial counts were detected in the samples taken from offices $17168 \mathrm{cfu} / \mathrm{m}^{3}$. Whereas, the general means of Staphylococci counts $\left(\mathrm{cfu} / \mathrm{m}^{3}\right)$ in corridors, offices, laboratories and toilets were found to be 7811 , 6668,5750 and $4920 \mathrm{cfu} / \mathrm{m}^{3}$, respectively (table 1). The obtained results indicated that, the counts of fungi were 4516, 4046, 3010 and $2567 \mathrm{cfu} / \mathrm{m}^{3}$ in laboratories, corridors, toilets and offices respectively.

Data revealed that higher prevalence of microbial load was detected in toilets and corridors. Our results are in agreement with those obtained by (Kalogerakis, et al. 2005; Karwowska, 2005; Di Giulio, et al. 2010; Hayleeyesus and Manaye 2014; Jurado, et al. 2014 and Mohan, et al. 2014).

Moreover, the higher concentrations could be attributed to personal activities (talking, sneezing, walking and coughing), flower pots, equipments, outside air and closed conditioning systems (Kalogerakis et al. 2005).

Therefore, the ventilation rates can be very essential to protect the occupant's health and decrease the indoor microbial load.

In conclusion, almost all the sampling sites were heavily contaminated with bacteria and fungi. Thus, attention must be given to control the environmental factors which favor the cross contamination in indoor occupational environment to prevent adverse health effects.
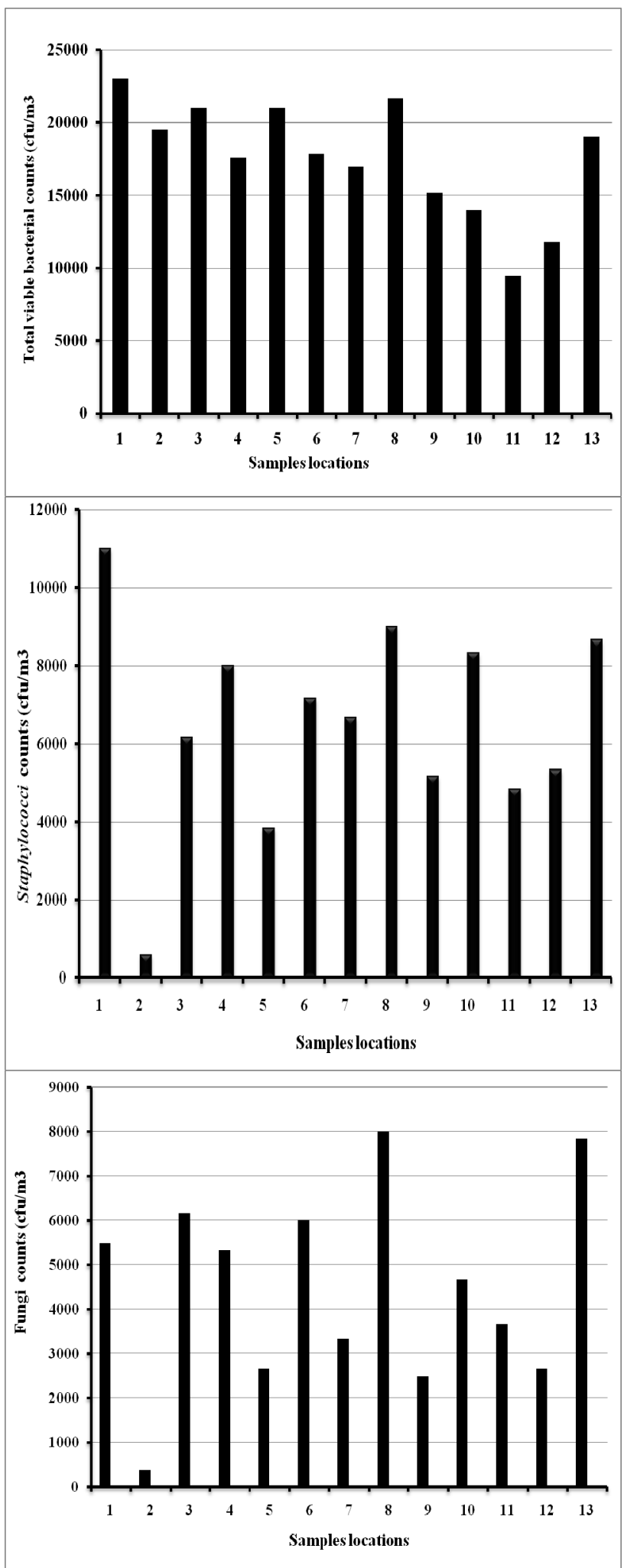
Fig. 2. Total viable bacteria, Staphylococci and fungi counts $(\mathrm{cfu} / \mathrm{m} 3)$ of air samples taken from laboratories.

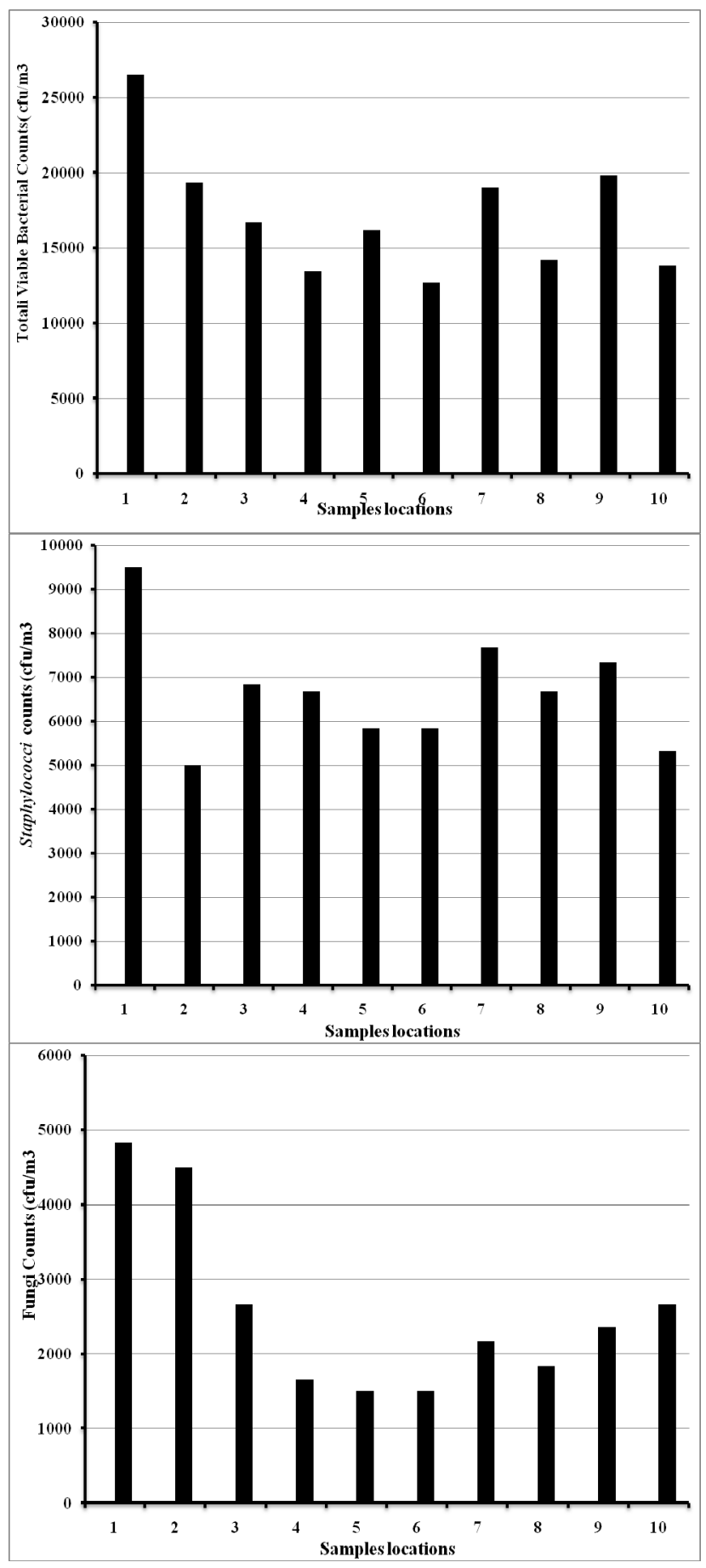

Fig. 3. Total viable bacteria, Staphylococci and fungi counts (cfu/m3) of air samples taken from offices.
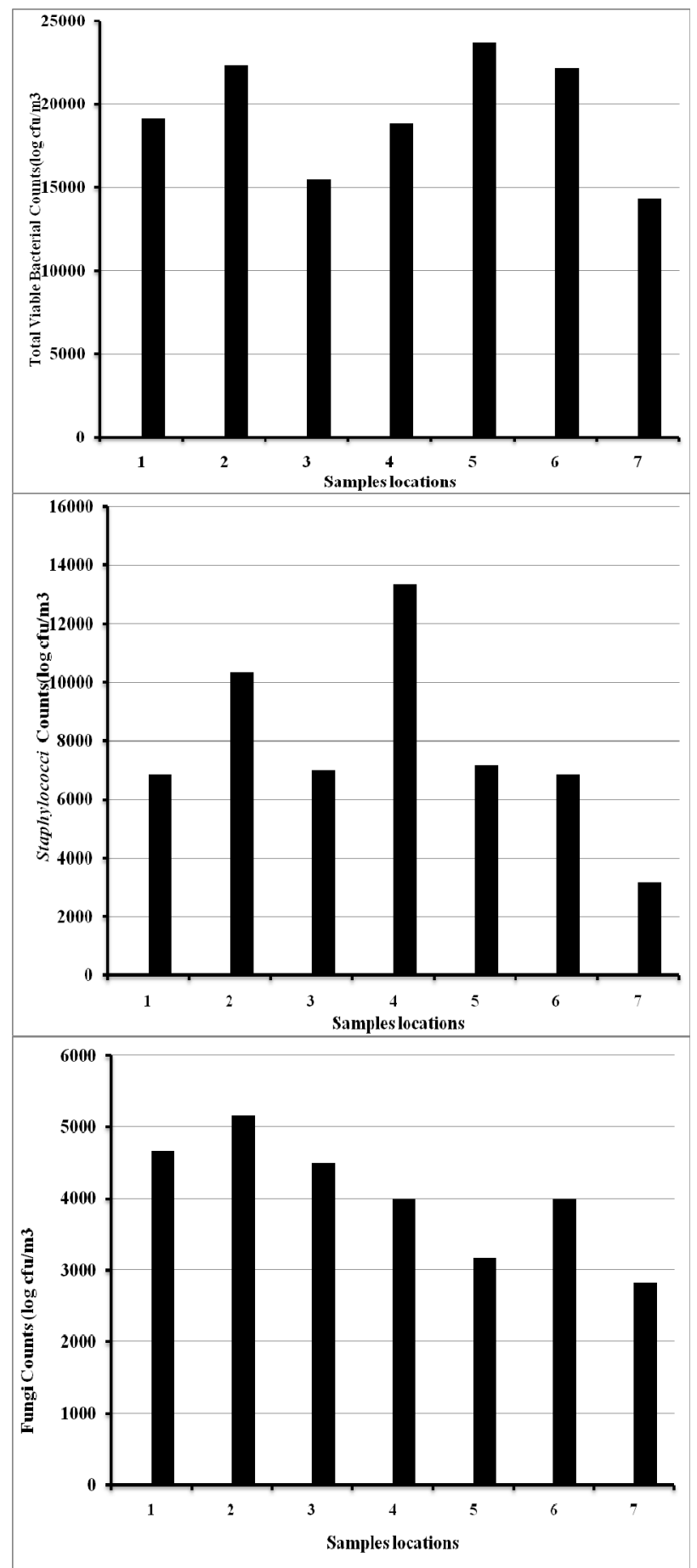
Fig. 4. Total viable bacteria, Staphylococci and fungi counts $(\mathrm{cfu} / \mathrm{m} 3)$ of air samples taken from corridors.

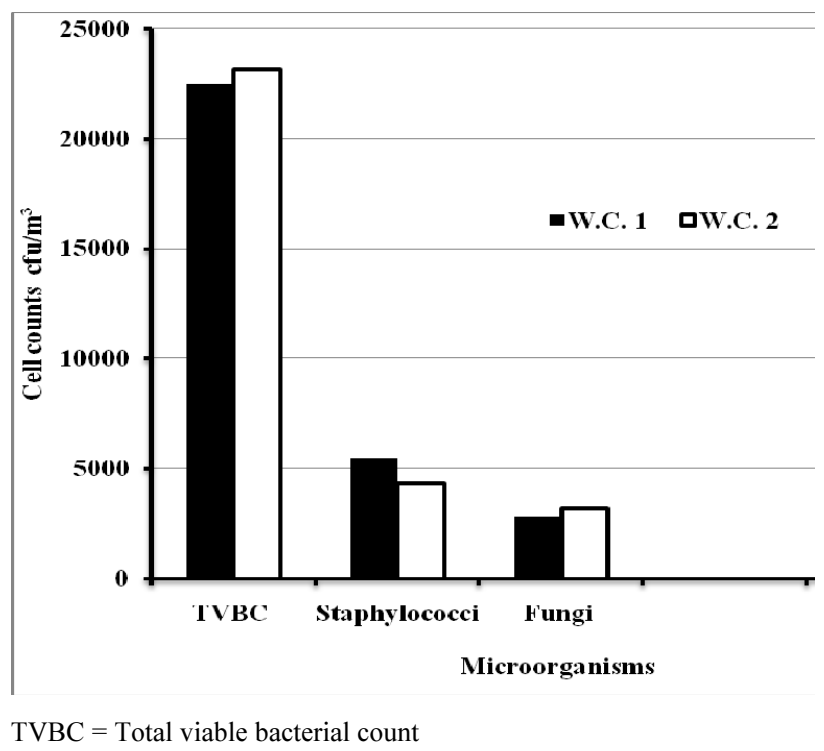

Fig. 5. Total viable bacteria, Staphylococci and fungi counts $(\mathrm{cfu} / \mathrm{m3})$ of air samples taken from toilets.

Table 1. Means of bacteria and fungi counts $(\mathrm{cfu} / \mathrm{m} 3)$ in different sampling sites.

\begin{tabular}{|c|c|c|c|c|}
\hline & & \multicolumn{3}{|c|}{$\begin{array}{c}\text { Bacteria and fungi counts } \\
\text { (cfu/m3) }\end{array}$} \\
$\begin{array}{c}\text { Sampling } \\
\text { sites }\end{array}$ & $\begin{array}{c}\text { Number } \\
\text { of } \\
\text { samples }\end{array}$ & TVBC* & Staphylococci & Fungi \\
\cline { 3 - 5 } & 117 & 17548 & 5750 & 4516 \\
\hline Laboratories & 90 & 17168 & 6668 & 2567 \\
\hline Offices & 63 & 19435 & 7811 & 4046 \\
\hline Corridors & 18 & 22833 & 4920 & 3010 \\
\hline Toilets & &
\end{tabular}

TVBC* = Total viable bacterial count.

\section{References}

Abdel Hameed, A. A. and Farag S. A. (1999) An indoor biocontaminants air quality, International Journal of Environmental Health Research, 9, 313.

Dacarro, C., Picco A. M., Grisoli, R. and Redolfi, M. (2003) Determination of aerial microbiological contaminations in scholastic sports environment, $J$. Appl., Microbiol., 95: 904 - 912.

Dhanasekaran, D., Thajuddin, N., Rashmi, M., Deepika, T. L. and Gunasekaran, M. (2009) Screening of biofouling activity in marine bacterial isolate from ship hull, Int. J. Environ. Sci. Tech., 6 (2): 197-202.

Di Giulio, M., Grand, R., Di Cmpli, E., Di Bartlomeo, S. and Cellini, L. (2010) Indoor air in University environments, Environ. Monit. Assess., 170: 509-517.

Dudzińska, M. (2011) Volatile Organic Compounds in Private Cars and Public Vehicles, Rocznik Ochrona Środowiska, Annual Set The Environment Protection, 13: 101-115.

Hayleeyesus, S. F. and Manaye, A. M. (2014) Microbiological Quality of Indoor Air in University Libraries, Asian Pacific J. of Tropical Biomedicine, $\mathbf{4}$ (1): S 312- S 317.

Huttunen, K., Rintala, H., Hirvonen, M. R., Vepsäläinen, A., Hyvärinen, A., Meklin, T. and et al. (2008) Indoor air particles and bioaerosols before and after renovation of moisture-damaged buildings: the effect on biological activity and microbial flora, Environmental Research, 107: 291-298.

Jurado, S. R., Bankoff, A. D. P. and Sanchez, A. (2014) Indoor Air Quality in Brazilian Universities, Int. J. Environ. Res. and Public Health, 11: 7081-7093.

Kalogerakis, N., Paschali, D., Lekaditis, V., Pantidou, A., Eleftheriadis, K. and Lazaridis, M. (2005) Indoor air quality - bioaerosol measurements in domestic and office premises, J. Aerosol Science, 36: 751-761.

Kalwasińska, A., Burkowska, A. and Wilk, I. (2012) Microbial air contamination in indoor environment of a university library, Annals of Agricultural and Environmental Medicine, 19 (1): 25-29.

Karwowska, E. (2005) Microbiological air contamination in farming environment, Pol. J. Environ., Stud., 14: 445449 .

Kim, K. Y. and Kim, C. N. (2007) Airborne microbiological characteristics in public buildings of Korea, Building and Environment, 42: 2188-2196.

Naga Madhan Mohan, K., Ramprasad, S. and Maruthi, Y. A. (2014) Microbiological quality of indoor air in primary and secondary schools of Visakhapatnam, India. Int. J. Curr. Microbiol App. Sci., 3 (8): 880-887.

Reynolds, S. J., Black, D. W., Borin, S. S., Breuer, G., Burmeister, L. F., Fuortes, L. J., Smith, T. F., Stein, M. A., Subramanian, P., Thorne, P. S. and Whitten, P. (2001) Indoor Environmental Quality in Six Commercial Office Buildings in the Midwest United States, Journal: Applied Occupational and Environmental Hygiene, 16 (11): 1065 -1077.

Shaughnessy, H., U., Turunen, M., Metsämuuronen, J., Palonen, J., Putus, T., Kurnitski, J. and Shaughnessy, R. (2012) Sixth grade pupils' health and performance and indoor environmental quality in Finnish school buildings, Br. J. Educ. Res., 2: 42-58. 
Srikanth, P., Sudharsanam, S. and Steinberg, R. (2008) Bioaerosols in indoor environment: Composition, health effects and analysis, Indian Journal of Medical Microbiology, 26: 302 - 312.

Stanley N. J., Kuehn, T. H., Kim, S. W., Raynor, P. C., Anantharaman, S., Ramakrishnan, M. A. and Goyal, S. M. (2008) Background culturable bacteria aerosol in two large public buildings using HVAC filters as long term, passive, high-volume air samplers, Journal of Environmental Monitoring, 10: 474-481.

Stryjakowska-Sekulska, M., Piotraszewska-Pająk, A., Szyszka, A., Nowicki, M. and Filipiak, M. (2007)
Microbiological Quality of Indoor Air in University Rooms Polish, J. of Environ. Stud., 16 (4): 623-632.

Wamedo S. A., Ede, P. N. and Chuku, A. (2012) Interaction between building design and indoor airborne microbial load in Nigeria, Asian J. Biol. Sci., 5: 183- 191.

World Health Organization (2013) WHO guidelines for indoor air quality: dampness and mould. Copenhagen, Denmark: Available from: http://www. euro.who.int/ data/assets/pdf file/0017/43325/E92645 (Accessed on $24^{\text {th }}$ November, 2013). 
التقييم الميكروبي لبيئة العمل المهنية في إحدى كليات جامعة الملك عبدالعزيز بجدة منصور أحمد بالخيور وأحمد محمد معوض مبروك

قسم العلوم البيئية، كلية الأرصاد والبيئة وزراعة المناطق الجافة، جامعة الدلك عبدالعزيز، جذة، المهلكة العربية السعودية

الدستخلص. إن تواجد الكائنات الحية الدقيقة في هواء الأماكن المغلقة يمكن أن يسبب العديد من المشكلات الصحية الخطيرة. لذلك كان الهدف من إجراء هذا العمل هو تتبع بعض مجموعات الكائنات الحية الدقيقة

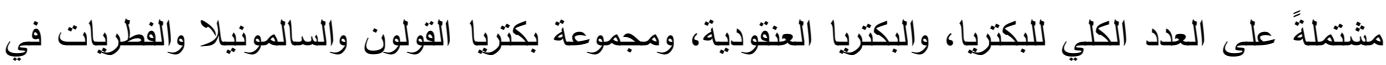
مواقع مختلفة من بيئة العمل المهنية في كلية الأرصاد والبيئة وزراعة المناطق الجافة الكية.

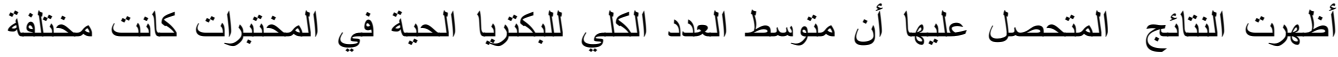

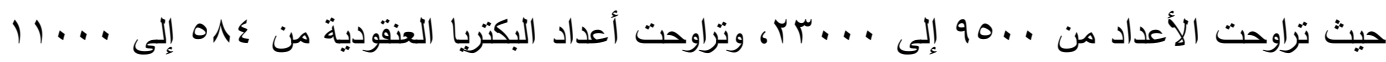

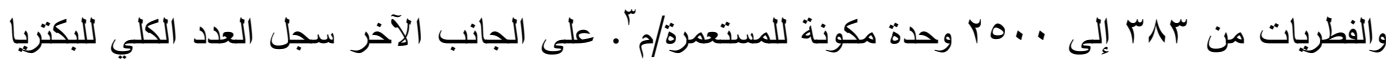

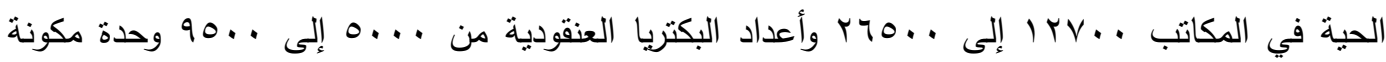

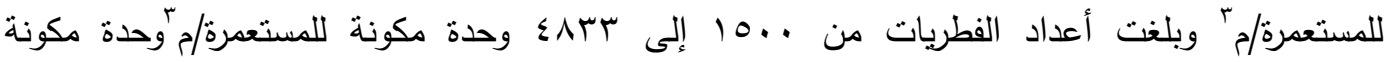

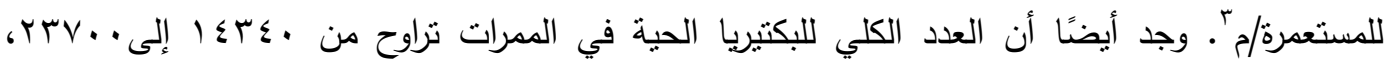

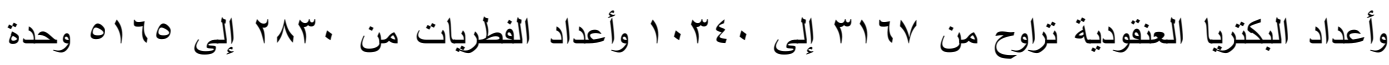

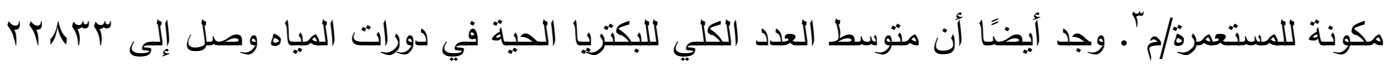

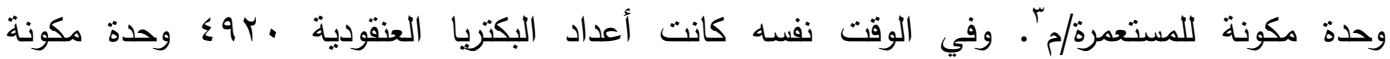

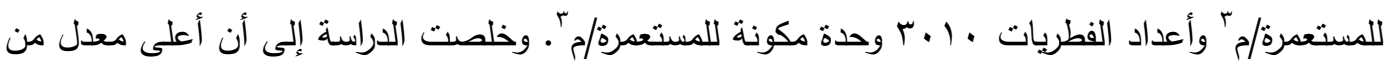

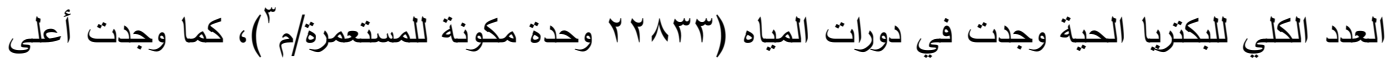

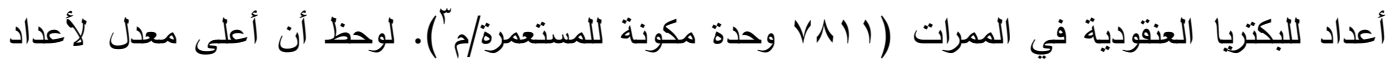

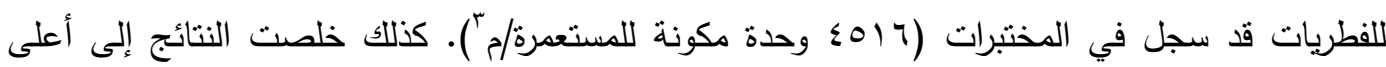

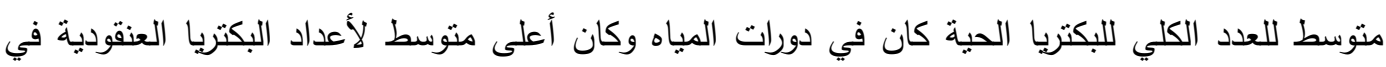

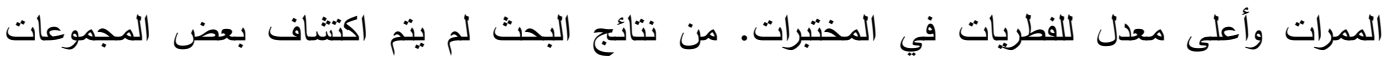
الميكروبية مثل: بكتبريا القولون والخمائر والسالمونيلا في جميع مواقع أخذ العينات (المكاتب والمختبرات

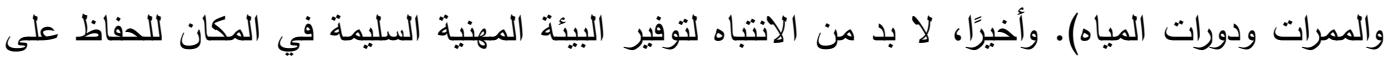
صحة الطلاب والعاملين أيضًا. الكلمات الدفتاحية: الهواء الداخلي، الكائنات الدقيقة، البكتيريا المتواجدة بالهواء، المشاكل الصحية والبيئة 